\title{
Basic Assumptions of Organizational Behavior
}

\author{
Bhupindra Jung Basnet, MPhil \\ Lecturer \\ Nepal Commerce Campus, Faculty of Management, T.U.
}

\begin{abstract}
The purpose of this paper is to do in depth analysis of the basic assumptions of organizational behavior. This paper is based on conceptual base reviewed from different books and research reports. The objective of the study is to identify the basic assumptions of organizational behavior. The paper concludes that there are two types of basic assumptions of organizational behavior. They are nature of people and nature of organizations. A basic assumption about nature of people incorporates individual differences, a whole person, motivated behavior, value of the person, selective perception, and desire for involvement. A basic assumption about nature of organizations involves social system, mutuality of interest, and ethical treatment.
\end{abstract}

Keywords: organizational behavior, the assumption about nature of people, the assumption about nature of organizations

\section{Introduction}

Organizational behavior is concerned with analyzing, understanding, predicting, and managing human behavior in the organization for improving organizational effectiveness. Organizational behavior is the study of human behavior, attitudes, and performance in organization (Singh, 2015). Organizational behavior actually refers to the behavior of people in organization. Organizational behavior focuses on the behavior, attitudes, and performance of people in organizations (Heath \& Sitkin, 2001) Organizational behavior is a field of study that endeavors to understand, explain, predict, and change human behavior as it occurs in the organizational context.

Organization is the systematic process two or more people together to achieve common objectives (Barnard, 1938). Behavior is the activities of the person while doing the job. Behavior refers to what people do in the organization, how they perform, and what their attitudes are in organization. Organizational behavior is frequently applied to address workplace issues such as absenteeism, turnover, productivity, motivation, working in groups, and job satisfaction. Organizational behavior is the study of human behavior in the organization (Moorhead, Griffin, Irving \& Coleman, 2000).

The different theory and concepts of organizational behavior come from psychology, social psychology, sociology, anthropology, and political science. Organizational behavior is the process of understanding, predicting and managing of human behavior in organizations (Luthans, 2011). The objective of study is to identify basic assumption of organizational behavior in organization.

\section{Research Methodology}

This research is based on qualitative research design. Descriptive qualitative research is used to identify the basic assumptions of organizational behavior through the books, journal, and articles. The basic assumptions of organizational behavior are nature of people (individual differences, a whole person, 
selective perception, motivated behavior, value of the person and desire for involvement) and nature of organizations (social system, mutuality of interest, and ethical treatment).

\section{Basic Assumptions (Foundations of OB) of Organizational Behavior}

Organizational behavior bases on two fundamental assumptions. Nature of people and nature of organization are used foundations of organizational behavior. Individual differences, a whole person, caused behavior, and human dignity are practiced in nature of people and social systems, mutuality of interests, and holistic concept are applied in nature of organization (Aswathappa, 2017). In figure 1, there are two types basic assumptions of $\mathrm{OB}$. They are the assumptions about nature of people and the assumptions about nature of organization (Poudyal \& Pradhan, 2018; Gautam \& Gautam, 2019).

Figure 1: Foundations of OB

\begin{tabular}{|c|c|c|}
\hline & \multicolumn{2}{|c|}{ Basic Assumptions/ Foundations of OB } \\
\hline \multicolumn{2}{|c|}{ Assumptions about Nature of People } & \multirow{6}{*}{$\begin{array}{l}\text { Assumptions about Nature of } \\
\text { Organization } \\
\text { 1. Social system } \\
\text { 2. } \quad \text { Mutuality of interest } \\
\text { 3. } \quad \text { Ethical treatment (ethical behavior) }\end{array}$} \\
\hline & Individual differences & \\
\hline 2 . & A whole person & \\
\hline 3. & Selective perception & \\
\hline 4. & Motivated behavior & \\
\hline \multirow{2}{*}{\multicolumn{2}{|c|}{$\begin{array}{l}\text { 5. Value of the person (Human value) } \\
\text { 6. Desire for involvement }\end{array}$}} & \\
\hline & & \\
\hline
\end{tabular}

\section{A. The Assumptions about Nature of People}

It is necessary to understand basic assumptions about the nature of people for understanding organizational behavior. The following are the basic assumptions about nature of people.

\section{Individual Differences}

Organizational behavior assumes that all the individuals are differences from each other. The difference in individuals can be in several ways like physical characteristics, intelligence, perception, personality, attitudes, aptitudes, emotion, learning capability and communicative ability.

\section{A Whole Person}

Organizational behavior assumes that an individual should be considered as a whole person. We cannot separate individual's psychology, beliefs, values, attitude from physical work settings.

\section{Selective Perception}

Perception is a process by which individuals organize and interpret their sensory impressions in order to give meaning to the environment (Robbins, 1997). Perception is an individual's own view. Each person has a unique way to see, organize and interpret about event, people and things.

\section{Motivated Behavior}

Motivation is the willingness to do something to achieve organizational goals and, at the same 
Vol. 4, No. 1

time, to satisfy individual needs (Templer, Cattaneo, DeCenzo \& Robbins, 2000). Every employee expects motivated behavior from manager. Manager need to understand about how employees can be motivated for better performance.

\section{Value of the Person}

Organizational behavior assumes that people are more valuable and different than non-living things. Employees should be treated with respect, dignity and equity by the organizations. Employees should not be treated only economic tools.

\section{Desire for Involvement}

Individuals have desire for involvement in work. They want to show their creativity, skills, and efficiency while doing the work. People have capabilities for task performance, role fulfillment, and meaningful contribution and to meet challenging situations.

\section{B. The assumptions about Nature of Organizations}

The nature of organizations is the area of study of organizational behavior. There are following basic assumption about nature of organizations.

\section{Social System}

Organizations are the part of social system. Organizations are operated by social and psychological laws. Organizational behavior assumes that organizations are open social system. These systems affect behavior of individual.

\section{Mutuality of Interest}

Organizational behavior assumes mutuality of individual and organization interests. Interests flow both ways. Organizations need people and people need organizations. Mutual interest provides a common goal for all the participants, which results in encouragement of the people to solve problems of the organization.

\section{Ethical Treatment}

Ethics involves moral issues and choices. It deals with right or wrong behavior about event, people and things. Ethical behavior of an individual depends on the moral standard or codes of conduct determined by society. Managerial ethics is the standard of behavior that guides individuals' managers in their work. Organizational should establish rules, code of conduct, working procedures and system.

\section{Conclusions}

The basic assumption of organizational behavior is two types. They are nature of people and nature of organization. A basic assumption about nature of people incorporates individual differences, a whole person, motivated behavior, value of the person, selective perception, and desire for involvement. A basic assumption about nature of organizations involves social system, mutuality of interest, and ethical treatment.

\section{References}

Aswathappa, K. (2017). Organizational Behavior. $12^{\text {th }}$ ed. Mumbai: Himalaya Publishing House Pvt. Ltd. Barnard, C. I. (1938). The Functions of the Executive. Cambridge, Mass.: Harvard University Press, p. 73. Gautam, D. K., \& Gautam, P. K. (2019). Organizational Behavior. $2^{\text {nd }}$ ed. Kathmandu: KEC Publication and Distribution Pvt. Ltd.

Heath, C., \& Sitkin, S. B. (2001). Big-B versus Big-O: What Is Organizational about Organizational Behavior? Journal of Organizational Behavior 22: 43-58.

Luthans, F. (2011). Organızational Behavior: An Evidence-Based Approach. McGraw-Hill/Irwin.

Moorhead, G., Griffin, R. W., Irving, P. G., \& Coleman, D. F. (2000). Organizational Behavior. Boston: 
Houghton Mifflin Company.

Poudyal, S. R., \& Pradhan, G. M. (2018). Organizational Behavior. $2^{\text {nd }}$ ed. Kathmandu: Kriti Publication Pvt. Ltd.

Robbins, S. P. (1997). Essentials of Organizational Behavior. New Delhi: Prentice Hall of India.

Robbins, S. P., Judge, T. A., \& Vohra, N. (2013). Organizational Behavior. $15^{\text {th }}$ ed. India: Pearson education Singh, K. (2015). Organizational Behavior. $3^{\text {rd }}$ ed. India: Vikas Publishing House Pvt Ltd.

Templer, A. J., Cattaneo, R. J., DeCenzo, D. A.. \& Robbins, S. P. (2000). Human Resource Management. John Wiley. 